\title{
The incidence of spine deficiencies among disabled students with intellectual disabilities from special education system in Bucharest
}

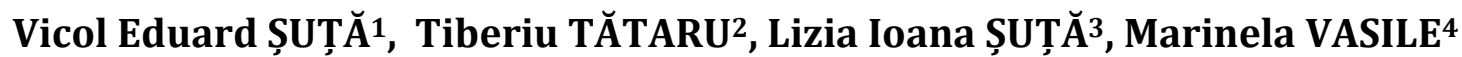

\begin{abstract}
The aim of the research was to emphasize the incidence of spine deficiencies in students with intellectual disabilities involved in the recovery program within the kinetotherapy classes carried out in special schools in Bucharest.

We wanted to point out that among the two categories of children with disabilities enrolled in special education from Bucharest (children with mild / moderate intellectual disabilities and children with serious / severe / profound intellectual disabilities) there are no statistical differences related to the incidence of spine deficiencies.

Research sample consisted of students enrolled in special education from 11 schools. Thus there were formed two groups of students: students with mild / moderate intellectual disabilities and children with serious / severe / profound intellectual disabilities. Another criterion for forming working groups was the school level. Thus, each category was divided into subjects enrolled in primary education and subjects enrolled in secondary education.

The comparison made between the groups revealed that in terms of the incidence of spine deficiencies there is correlation between the type of physical deficiency and the degree of disability.
\end{abstract}

Key words: special education sistem; primary and secondary education; intellectual disabilities, physical deficiencies

\section{Rezumat}

Scopul cercetării a fost acela de a reliefa incidența deficiențelor fizice la nivelul coloanei vertebrale, la elevii cu dizabilități intelectuale, implicați în programul de recuperare în cadrul orelor de kinetoterapie desfăsurate în școlile speciale din București.

În cadrul lucrării ne-am propus să evidenţiem faptul că între cele două categorii de copii cu dizabilități, școlarizați la nivelul învățământului special din București (copii cu deficiență mintală ușoară / moderată și copii cu deficiență mintală severă /profundă / asociată) nu există diferențe statistice din punct de vedere al incidenței deficiențelor fizice la nivelul coloanei vertebrale.

Eşantionul cercetării a fost format din elevi școlarizați la nivelul învățământului special în cele 11 școli. Astfel, au fost formate două grupe de elevi: elevi cu deficiență mintală ușoară / moderată și elevi cu deficiență mintală severă / profundă / asociată. Un alt criteriu de formare a grupelor de lucru l-a constituit nivelul de școlarizare. Astfel, fiecare categorie de subiecți a fost împărțită în elevi școlarizați la nivel primar și elevi școlarizați la nivel gimnazial.

În urma comparaţiilor realizate între grupurile de elevi constituite a reieșit că din punct de vedere al incidenței deficiențelor fizice la nivelul coloanei vertebrale există legătură între tipul de deficiență fizică și gradul dizabilității.

Cuvinte cheie: învățământ special, nivel primar și gimnazial, dizabilitate intelectuală, deficiențe fizice

\footnotetext{
${ }^{1}$ Assist. Prof., Bucharest University, Romania, e-mail: vicol79@yahoo.com

2 Assoc. Prof., Constantin Brancusi University, Targu Jiu, Romania

${ }^{3}$ Teacher, Special School Constantin Paunescu, Bucuresti, Romania

${ }_{4}$ Teacher, Special School Constantin Paunescu, bucuresti, Romania
} 


\section{Introduction}

In this paper we intend to present the spine physical deficiencies of the students with intellectual disabilities involved in the kinetic program recovery carried out in special schools from Bucharest. This study is a pilot ascertaining study, data centralization at the level of special education system conducting to management decisions. In this respect, we consider appropriate to achieve an overview of the special education system.

There are 11 schools in Bucharest where children with intellectual disabilities are enrolled at primary and secondary level. Each of the 11 special schools enrolled children by type of deficiency. There are classes for students with intellectual disabilities, enrolled according to the degree of deficiency, in classes for students with mild / moderate deficiency and in classes for serious / severe / profound deficient students.

In this period, it is aimed to match the curriculum and educational plans according to the Strategic Priorities of the Ministry of Education, to the sectorial action plans for 2016 and to note 31680/06.04.2016 of the Ministry of Education and Scientific Research regarding the development of the curriculum in secondary schools. We believe necessary to know about the incidence of physical deficiencies to students with disabilities in order to develop the curriculum in accordance with the students' needs and also to include a number of hours per class in the curriculum.

We mention that such a study was achieved in the school year 2012 - 2013 at the level of special education in Bucharest whose survey results were presented to the Methodical Commission of Kinesiotherapy Teachers from Bucharest.

The results of a study on the prevalence of chronic diseases in children and youth from communities were presented in the Health National Report of Children and Youth from Romania published in 2011 by the National Institute of Public Health. Thus, between 2005 and 2011, studying the prevalence of chronic diseases in the population aged between 3 and 22 years old, it was found that after ocular diseases, stature-weight hypotrophy, rickets and obesity sequelae and spinal deformities represent the 5 th cause of disease.
Studies on the incidence of physical deficiencies were presented at international level and among people with disabilities and were done on different categories of subjects: children with Down syndrome, autistic people and obese persons.

\begin{abstract}
Aim of the research
Our aim is to improve the kinesiotherapeutic recovery process in special education, by detecting spine physical deficiencies in students with intellectual disabilities aged between 7 and 18 years old. The purpose of research is to establish the incidence of spine physical deficiencies in students with intellectual disabilities enrolled in the special education schools from Bucharest in order to adapt proper design and planning documents.
\end{abstract}

\section{Objectives of the research}

The objectives of this research are:

1. Setting the level of knowledge by summarizing some general information about the physical deficiencies in children with intellectual disabilities.

2. Evaluation of body attitudes to children with intellectual disabilities enrolled in special education.

3. Centralization of data on the involvement of children with intellectual disabilities from special education from Bucharest in the kinesiotherapeutic program.

4. Comparing the incidence of physical deficiencies in students with intellectual disabilities respecting the criterion which aimed to define the degree of deficiency.

5. Highlighting the percentage differences in terms of spine physical deficiencies between students with mental deficiency, mild / moderate mental deficiency on one side and serious / severe / profound mental deficiency on the other hand.

\section{Hypothesis of the research}

Detecting physical deficiencies in students with mental deficiency, students with mild / moderate mental deficiency on one side and serious / severe / profound mental deficiency on the other hand allows the identification of small differences in percentage, in terms of incidence for this two categories of subjects. 


\section{Materials and methods \\ Science research tasks}

The tasks set after the formulation of research objectives were:

1. Reading the literature and finding information related to the right and poor posture of the body.

2. Providing evidence, measurements and assessment tests through which we will detect the spine deficiencies [1], for the children with intellectual disabilities.

3. Detecting general or segmental spine deviations as a result of the assessment of body posture [2] in children with intellectual disabilities.

4. Setting up a database with information on the existence physical deficiencies in students with intellectual disabilities involved in the kinesiotherapeutic program at the level of special education in Bucharest.

5. Establishing the number of subjects involved in the kinesiotherapeutic program at the level of special education in Bucharest, for each of the spine deficiencies.

6. Fixing the percentages of subjects involved in the recovery program, for each type of the physical disabilities and each type of subject (students with mild / moderate mental deficiency on one side and serious / severe / profound mental deficiency on the other hand).

7. Data analysis, processing and interpretation.

8. Formulation of final conclusions.

\section{Research sample. Experimental groups}

To achieve the research a total number of 1701 children enrolled at the 11 schools offering special education services for students with intellectual disabilities in Bucharest for primary and secondary level were involved. It should be noted that the group of students with mental deficiency consists of 972 students with mild / moderate mental deficiencies and 729 students with serious / severe / profound mental disability. We mention that the assessment was carried out during kinesiotherapeutic program in the initial assessment at the beginning of the school year 2015-2016. The group of subjects consisted of all students with disabilities from special education schools in Bucharest enrolled at primary and secondary level (Table 1).
Table 1. Distribution of students by sufficiency degrees and levels of education

\begin{tabular}{|c|c|c|c|c|c|}
\hline $\begin{array}{l}\text { Educational } \\
\text { institution }\end{array}$ & 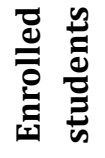 & 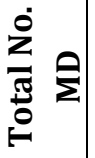 & 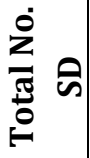 & 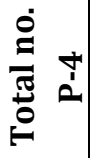 & 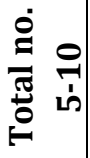 \\
\hline $\begin{array}{l}\text { Special School } \\
\text { no } 1\end{array}$ & 153 & 58 & 95 & 72 & 81 \\
\hline $\begin{array}{l}\text { Special School } \\
\text { no } 2\end{array}$ & 113 & 67 & 46 & 51 & 62 \\
\hline $\begin{array}{l}\text { Special School } \\
\text { no } 3\end{array}$ & 137 & 89 & 48 & 63 & 74 \\
\hline $\begin{array}{l}\text { Special School } \\
\text { no } 4\end{array}$ & 147 & 88 & 59 & 71 & 76 \\
\hline $\begin{array}{l}\text { Special School } \\
\text { no } 5\end{array}$ & 212 & 107 & 105 & 91 & 121 \\
\hline $\begin{array}{l}\text { Special School } \\
\text { no } 6\end{array}$ & 175 & 98 & 77 & 82 & 93 \\
\hline $\begin{array}{l}\text { Special School } \\
\text { no } 7\end{array}$ & 144 & 95 & 49 & 61 & 83 \\
\hline $\begin{array}{l}\text { Special School } \\
\text { no } 8\end{array}$ & 155 & 118 & 37 & 64 & 91 \\
\hline $\begin{array}{l}\text { Special School } \\
\text { no } 9\end{array}$ & 147 & 109 & 38 & 58 & 89 \\
\hline $\begin{array}{l}\text { Special School } \\
\text { No } 10\end{array}$ & 95 & 31 & 64 & 33 & 62 \\
\hline $\begin{array}{l}\text { Special School } \\
\text { no } 11\end{array}$ & 223 & 112 & 111 & 92 & 131 \\
\hline TOTAL & 1701 & 972 & 729 & 738 & 963 \\
\hline
\end{tabular}

Abbreviations:

MD - children with moderate mental deficiency

MS - children with severe mental deficiency

P-4 - children enrolled in preparatory class-4th grade

$5-10$ - children enrolled in $5^{\text {th }}$ grade- $10^{\text {th }}$ grade

\section{Assessment methods}

In this section we will present the discipline kinesiotherapy within the curricula and special education system.

The program of activities with students with disabilities enrolled in special education system is imposed by the curriculum as in the case of the other schoolchildren. Thus, at present, the activity in special schools is conducted according to curriculum 4928/08.09.2005 for special education institutions which educate children with 
serious/severe/profound deficiencies, to curriculum 4927/08.09.2005 for special education institutions which educate children with mild/moderate disabilities at primary level and to curriculum 5329/01.09.2008 for special education institutions which educate children with mild/moderate disabilities at secondary level [3]. In the three curricula in force and only in the special education there is the 8th curriculum called Specific and Compensation Therapies. For students with mild/moderate disabilities, the disciplines from the curriculum called Specific and Compensation Therapies are: Kinesiotherapy, Psycho-diagnosis, Educational Counseling and Guiding and Specific Therapies and Activities. For students with serious/severe/profound disabilities in the same curriculum there are the following disciplines: Language Disorders Therapy, Kinesiotherapy and Psycho-diagnosis, Counseling, Therapy and Intervention Programs.

In conclusion, the discipline Kinesiotherapy is provided in the curricula for all types and degrees of deficiency. Thus, classes of students with mild / moderate mental disabilities have one hour of kinesiotherapy per week and classes of students with serious / severe / profound disabilities have two hours of kinesiotherapy per week.

Kinesiotherapy teachers make an assessment of all schoolchildren at the beginning of each school year during the initial assessment [4]. In the first two weeks during the assessment of musculoskeletal apparatus it is carried out the assessment of physical growth and development by subjective methods - somatoscopy- and by objective methods instrumental somatoscopic examination [5]. In the third week, the last stage of the initial assessment for students individual records of evaluation are established where all the information obtained in the anamnesis conducted with family members appear, information obtained from the files of children from the Internal Commission of Assessment. The assessments are: somatometry, prehension assessment, walking agility, ROM RANGE OF MOTION articular amplitude assessment, and muscle strength and effort capacity assessment. When the teacher discovers diseases of the locomotor system, he directs students to the school doctor or the general practician in order to confirm the diagnosis and to present the associated disease which appears in the medical records. (Table 2)

Table 2. The distribution of children with intellectual disabilities involved in physical therapy activities in the special education system in Bucharest

\begin{tabular}{|c|c|c|c|}
\hline $\begin{array}{c}\text { Educational } \\
\text { institution }\end{array}$ & $\begin{array}{l}\text { Enrolled } \\
\text { students }\end{array}$ & $\begin{array}{c}\text { No. of } \\
\text { kinesio } \\
\text { therapy } \\
\text { lesons }\end{array}$ & $\begin{array}{c}\text { No. of } \\
\text { involved } \\
\text { students }\end{array}$ \\
\hline $\begin{array}{l}\text { Special School } \\
\text { no } 1\end{array}$ & 153 & 22 & 39 \\
\hline $\begin{array}{l}\text { Special School } \\
\text { no } 2\end{array}$ & 113 & 17 & 17 \\
\hline $\begin{array}{l}\text { Special School } \\
\text { no } 3\end{array}$ & 137 & 18 & 29 \\
\hline $\begin{array}{l}\text { Special School } \\
\text { no } 4\end{array}$ & 147 & 30 & 37 \\
\hline $\begin{array}{l}\text { Special School } \\
\text { no } 5\end{array}$ & 212 & 44 & 79 \\
\hline $\begin{array}{l}\text { Special School } \\
\text { no } 6\end{array}$ & 175 & 50 & 44 \\
\hline $\begin{array}{l}\text { Special School } \\
\text { no } 7\end{array}$ & 144 & 21 & 21 \\
\hline $\begin{array}{l}\text { Special School } \\
\text { no } 8\end{array}$ & 155 & 26 & 51 \\
\hline $\begin{array}{l}\text { Special School } \\
\text { no } 9\end{array}$ & 147 & 17 & 18 \\
\hline $\begin{array}{l}\text { Special School } \\
\text { no } 10\end{array}$ & 95 & 29 & 51 \\
\hline $\begin{array}{l}\text { Special School } \\
\text { no } 11\end{array}$ & 223 & 36 & 47 \\
\hline TOTAL & 1701 & 310 & 433 \\
\hline
\end{tabular}

\section{Results}

The data presented herein have been centralized as a result of the work carried out by a number of 22 kinesiotherapy teachers from 11 special education institutions from Bucharest.

We present below the main physical deficiencies encountered in students with intellectual disabilities and the number of children for each category. (Table 3) 
Table 3. The number of students involved in the kinesiotherapeutic program allocated on degrees of deficiency, levels of education and diseases.

\begin{tabular}{|c|c|c|c|c|c|c|}
\hline \multirow{2}{*}{$\begin{array}{c}\begin{array}{c}\text { Type of } \\
\text { deficiency }\end{array} \\
\begin{array}{c}\text { School } \\
\text { level }\end{array}\end{array}$} & \multicolumn{2}{|c|}{ MD } & \multirow{2}{*}{ 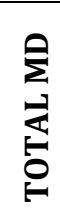 } & \multicolumn{2}{|c|}{ SD } & \multirow{2}{*}{ 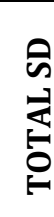 } \\
\hline & $\begin{array}{l}\dot{4} \\
\dot{2}\end{array}$ & $\begin{array}{l}0 \\
\text { i } \\
\text { i }\end{array}$ & & $\begin{array}{l}\dot{+} \\
\dot{1}\end{array}$ & $\begin{array}{l}\stackrel{0}{1} \\
1 \\
\text { in }\end{array}$ & \\
\hline Kyphosis & 16 & 24 & 40 & 11 & 18 & 29 \\
\hline Lordosis & 16 & 18 & 34 & 13 & 16 & 29 \\
\hline $\begin{array}{l}\text { Kypho- } \\
\text { lordosis }\end{array}$ & 4 & 12 & 16 & 5 & 14 & 19 \\
\hline $\begin{array}{c}\text { Scoliosis } \\
\text { C }\end{array}$ & 19 & 19 & 38 & 8 & 16 & 24 \\
\hline Scoliosis S & 3 & 8 & 11 & 5 & 8 & 13 \\
\hline $\begin{array}{l}\text { Kypho- } \\
\text { scoliosis }\end{array}$ & 3 & 12 & 15 & 5 & 4 & 9 \\
\hline $\begin{array}{c}\text { Neurologi } \\
\text {-cal } \\
\text { diseases }\end{array}$ & 13 & 13 & 26 & 38 & 51 & 89 \\
\hline $\begin{array}{c}\text { Other } \\
\text { diseases }\end{array}$ & 12 & 18 & 30 & 16 & 25 & 41 \\
\hline
\end{tabular}

Abbreviations:

MD - children with moderate mental deficiency

MS - children with severe mental deficiency

P-4 - children enrolled in preparatory class $-4^{\text {th }}$ grade

5-10 - children enrolled in $5^{\text {th }}$ grade- $10^{\text {th }}$ grade

Analyzing the data presented in Table no. 3, we can observe that in the kinesitherapy lessons conducted with children with intellectual disabilities the most frequent diagnoses of subjects are: kyphosis, lordosis, kypho-lordosis, scoliosis C, scoliosis S, kypho-scoliosis, neurological deseases and other deseases with reduced incidence.

Taking into consideration that the two groups of subjects involved in the research (students with mild / moderate mental disability and students with serious / severe / profound mental deficiency) does not consist of an equal number of students, we consider necessary to transform the number of students with a particular diagnosis in percentages, related to the total number from that category. (Table 4)

Table 4. The incidence of diagnoses in students involved in the kinesiotherapeutic program at the level of special education in Bucharest

\begin{tabular}{|c|c|c|}
\hline \multirow{2}{*}{ Sype of deficiency } & \multirow{2}{*}{$\begin{array}{c}\text { TOTAL } \\
\text { MD }\end{array}$} & \multirow{2}{*}{ TOTAL SD } \\
\cline { 1 - 2 } Kyphosis & $4,11 \%$ & $3,97 \%$ \\
\hline Lordosis & $3,49 \%$ & $3,97 \%$ \\
\hline Kypho-lordosis & $1,64 \%$ & $2,60 \%$ \\
\hline Scoliosis C & $3,90 \%$ & $3,29 \%$ \\
\hline Scoliosis S & $1,13 \%$ & $1,78 \%$ \\
\hline Kypho- scoliosis & $1,54 \%$ & $1,23 \%$ \\
\hline $\begin{array}{c}\text { Neurological } \\
\text { diseases }\end{array}$ & $2,67 \%$ & $12,20 \%$ \\
\hline Other diseases & $3,08 \%$ & $5,62 \%$ \\
\hline
\end{tabular}

\section{Discussions and conclusions}

Analyzing the data in Table 1 and Table 2 we can say that out of the 1,701 students enrolled at primary and secondary level in special education institutions from Bucharest for children with intellectual disabilities a number of 433 students representing a rate of $25.45 \%$ of all students were involved in the kinesiotherapeutic program.

We can observe that in the 11 special schools for children with intellectual disabilities 433 students are involved in a number of 310 kinesitherapy activities. This means that on average, working groups are made up of 1.39 students per activity. The conduct and organisation of kinesiotherapeutic program is different in terms of the number of students in a working group depending on the type and degree of deficiency.

In other personal studies we found that for the students with visual impairments the working groups in kinesiotherapeutic activities were formed on average from 1.23 students, and for the students with hearing deficiencies, the groups were formed on average of 2.42 pupils.

The low average regarding the composition of working groups for students with mental deficiency and visual impairments can be justified by the low space orientation capacity of the two categories of students and the desire to ensure children's safety during the lesson, while for students with hearing 
impairments, knowing the sign language goes beyond the barriers of communication. Also, low average on the composition of working groups for students with mental deficiency is due to the large number of students with neurological problems, students that usually work individually.

Comparing the data in Table 4 we can say that the hypothesis of the research is confirmed according to which the incidence of physical deficiencies is slightly different in children with disabilities enrolled in primary and secondary education depending on the grade of deficiency.

It can thus be seen that for students with serious / severe / profound mental deficiency is the most common disease are the neurological disorders. The most common disorder of the locomotor apparatus for this two category of children is attitudinal and structural kyphosis.

The present research is the first step in deepening knowledge of incidence of physical deficiencies to students with disabilities. All the obtained information will guide the development of organizational strategies for kinesiotherapy discipline at the level of School Inspectorate of Bucharest.

We intend to make a further research in to be checked if there are mathematical statistical correlations between the incidence of physical deficiencies and disability type and degree of children enrolled in special education system.

\section{References}

1. Antonescu D., Obraşcu C., Ovezea A. (1993). Corectarea coloanei vertebrale, Editura Medicală, București, 28-70.

2. Cordun M. (1999). Postura corporală normală şi patologică. Editura ANEFS, București, 92-152.

3. http://www.edu.ro/index.php/articles/c1023/ Planul-cadru de învățământ pentru clasele/grupele din învățământul special sau de masă care școlarizează elevi cu dizabilități moderate sau ușoare. (2008).

4. Horvat M., Block M. E., Kelly L. E. (2007). Developmental and Adapted Physical Activity Assessment, Human Kinetics, 137-157. 5. Jianu M. (2009). Noţiuni practice de ortopedie pediatrică de la nou-născut la adolescent, Pro Editură şi Tipografie, București, 5571. 